\title{
Relationship between tapping intensity and tapping panel dryness susceptibility of some clones of Hevea brasiliensis in Southwestern Côte d'Ivoire

\author{
Samuel Obouayeba ${ }^{1^{*}}$, Eric Francis Soumahin ${ }_{1}^{1,2}$, Koffi Mathurin Okoma ${ }^{3}$, \\ Aya Marie Chantal Kouadio Boko ${ }^{1}$, Koulaka Emmanuel Dick ${ }^{2}$, Régis Lacote
} \\ 1 \\ Centre National de Recherche Agronomique (CNRA), Station de Recherche de Bimbresso, Programme Hévéa, 01 BP 1536 Abidjan 01, Côte d'Ivoire, Tel : (225) 234541 76, Fax : (225) 23472122 Université de Cocody, UFR Biosciences, Laboratoire de Physiologie Végétale, 22 BP 582 Abidjan, Côte d'Ivoire, Tel/Fax : (225) 22444473 \\ Centre National de Recherche Agronomique, Laboratoire Central de Biotechnologie, $01 \mathrm{BP}$ 1740 Abidjan 01, Côte d'Ivoire, Tel : (225) 23472424 ; Fax : (225) 23472411 CIRAD, UR 34, Tree Crop Based Systems, TA B/34, Montpellier, France *Corresponding Author: E-mail: obouayebasam@yahoo.fr, Tel: (225) 234541 76, Fax: (225) 23472122
}

\begin{abstract}
It is well known that the productivity and the susceptibility to the tapping panel dryness (TPD) of Hevea brasiliensis are determined by the intrinsic feature of each clone but also by the tapping system. Thus, in order to establish the tapping system that minimizes the TDP occurrence an experiment was carried out in Côte d'Ivoire with four high yielding clones including, PB 235, PB 255, IRCA 18 and IRCA 111. Five tapping systems (d2 6d/7 0/y, d3 6d/7 4/y, d4 6d/7 6/y, d5 6d/7 $8 / y, d 66 \mathrm{~d} / 710 / \mathrm{y}$ ) were applied to these clones, corresponding to a range of $100 \%$ to $30 \%$ of tapping intensities. The results show that the occurrence of TPD is closely related to the tapping intensity and the tapping system which consists in tapping twice per week with one day rest $(S / 2$ d3 $6 \mathrm{~d} / 74 / \mathrm{y}$ ), was found to be the best tapping system. A quadratic relation was found between the rate of the TPD and the tapping intensity. Thus the clones IRCA 18 and IRCA 111, like PB 235 and PB 255, belong to the active metabolism clones. These clones also showed their adherence to the group of high rubber producer clones. This experiment also gave further evidence that the production of a tree for the tapping strongly depends on the intensity of tapping. It has also indicated that the intensity of tapping governed the tapping panel dryness rate among the clones having active metabolism, such as IRCA 18, IRCA 111, PB 235 and PB 255.
\end{abstract}

Keywords: Exploitation, quadratic curve relation, rubber tree, productivity, active metabolism, high rubber producer, Côte d'Ivoire.

\section{INTRODUCTION}

In Africa and particularly in Cote d'Ivoire, the exploitation or tapping system varies from one clone of rubber tree to another. The main factors that influence an exploitation system include the tapping and the hormonal stimulation. The tapping fluctuates from low ( $d 66 d / 7$ ) to high frequency (d3 6d/7) regardless to the metabolic activity, while the hormonal stimulation differs according to metabolic activity. A high hormonal stimulation is needed for the low metabolic activity clones (PB 217, IRCA 41, PR
107) and the contrary is required with the high one, like PB 260, PB 235, IRCA 18 (Jacob et al., 1988). For the medium metabolic activity clone such as GT 1 , a moderate hormonal stimulation is more suitable. The intensification of the exploitation could also consist in applying a high frequency of tapping, particularly the $\mathrm{d} 26 \mathrm{~d} / 7$. This type of exploitation is less or not practiced in Africa, but currently used in Southeast Asia. In fact, the intensification is increasingly proportional to the rubber production. However, clones with accelerated metabolism could 
Agric. Biol. J. N. Am., 2011, 2(8): 1151-1159

barely bear a strong hormonal stimulation, without a strong negative effect on its physiological future status, which might be affected by TPD (Dian, 1993; Obouayeba and Boa, 1993; Jacob et al., 1994; Dian et al., 1995). The tapping panel dryness (TPD) is one of the most destructive syndrome affecting rubber plantations and is becoming a matter of serious concern. The obvious symptom is the reduction of latex yield leading to total drying of the tapping panel (Jacob et al., 1984; Sethuraj, 1988; Krishnakumar et al., 2003; Jacob and Krishnakumar, 2005; Vijayakumar et al., 2006; Obouayeba et al., 2009). Most of the time, clones that are susceptible to the TPD have a high potential of production, but the weak reserves in sucrose within the latex predispose them to an important risk of physiological unbalance, under stimulation (Anonymous 1, 1993). Some of these clones include, PB 235 and PB 255, recognized as sensitive to tapping panel dryness in Asia (Anonymous 1, 1993). The clones IRCA 111, IRCA 18 developed in Côte d'Ivoire with PB 235 and PB 255 originating from Southeast Asia, are known as high rubber-producing clones (Anonymous 1 , 1993) which could increase the rubber production and improve the farmer revenues. Therefore, for these clones, there is a need to find the exploitation system that maintains a stable production over the years. In other words, to develop the exploitation system for each clone that could prevent the TPD. As mentioned beforehand, the exploitation system (tapping system), which includes the tapping frequency and the hormonal stimulation, could in some cases lead to the TDP. Thus the present study report the outcome of a survey conducted over a decade, in the southwest of Côte d'Ivoire, on four clones (IRCA 111, IRCA 18, PB 235 and PB 255), in order to assess the relationship between tapping intensity and tapping panel dryness susceptibility and determine the best tapping system for these clones.

\section{MATERIAL AND METHODS}

Plant material: The material consists of five clones including IRCA 111, IRCA 18, developed in Côte d'Ivoire, and PB 235, PB 255 introduced from Southeast Asia. They are a fast growing and vigorous clones, which could be opened at the $4^{\text {th }_{1} / 2}$ or $5^{\text {th }} \frac{1}{1 / 2}$ of its growth (Anonymous 1, 1993). Their growth during tapping is good. These clones present the features of clones having fast metabolism with good arrangements of rubber production. The trees used in the experimentation are those with comparable girth of around $49.5 \mathrm{~cm}$ in average with a CV of $0.6 \%$. Its yield potential is high indeed, but the low sucrose reserves within latex predispose it to high risks of physiological imbalance in the event of overstimulation (Jacob et al.,
1994). The trees (20-month grafted stumps) of clones (IRCA 18, IRCA 111, PB 235 and PB 255) was planted in June 1988 in laid out in straight lines, with a density of 500 trees per ha $(7 \mathrm{~m} \times 2.8 \mathrm{~m})$. RCB (Randomised Complete Bloc) of 6 treatments and 4 repetitions was used as experimental design with around 100 trees per plot.

Treatments: The trees were opened at height of $1.20 \mathrm{~m}$ (panel BO-1). The tapping systems imposed and intensity of tapping are show in table 1.

Stimulation: The trees were stimulated on panel and tapping cut with $1 \mathrm{~g}$ per tree of homogenized paste, which corresponds to $2.5 \%$ of Ethephon. The product used is ELS 50 Double Red diluted by 2 (1 weight of ELS $50+1$ weight of water).

\section{Measurements}

Yield : The yield was estimated by weighing the fresh coagulated rubber of each experimental unit every 4 weeks (28 days). For each treatment samples of $2 \mathrm{~kg}$ fresh coagulated rubber were used to calculate the transformation coefficient, which is used to determine the weight of dry rubber in gram per tree $\left(\mathrm{g} \cdot \mathrm{t}^{-1}\right)$, the weight in gram per tree per tapping $\left(\mathrm{g} \cdot \mathrm{t}^{-1} \cdot \mathrm{t}^{-1}\right)$ and the yield in kilogram per hectare $\left(\mathrm{kg} \cdot \mathrm{ha}^{-1}\right)$.

Moreover other parameters were determined annually:

Girth increment : Girth measured at $1.70 \mathrm{~m}$ from the ground

Tapping panel dryness: Tapping panel dryness, in order to get the rate of dry tapping cut length (LDC) and dry trees (DT)

Latex analysis: Sample of latex was used for biochemical parameters analysis including dry rubber content (DRC), sucrose (Suc), inorganic phosphorus (Pi) and thiol groups (RSH) contents. This analysis is carried out by the method of "latex micro diagnosis (Jacob et al., 1988)" (MDL). The dry rubber content is determined from $1 \mathrm{ml}$ of latex taken in each sample (treatment), which is weighted before and after setting with the drying oven during $24 \mathrm{~h}$. The difference in weight expressed as a percentage indicates the dry rubber content (DRC). Inorganic phosphorus (Pi), sucrose (Suc) and thiol groups (RSH) were measured from the trichloracetic acid (TCA) serum obtained by mixing $1 \mathrm{ml}$ of latex and $9 \mathrm{ml}$ of TCA $2.5 \%$. Then the coagulated rubber is taken and separated from mixture by using a rod. Then, the coagulated rubber was squeeze out and separated from TCA $2.5 \%$. Thus, sucrose content is measured out, in mmole per litre of latex (mM) by using the method of Ashwell (1957) based on anthrone.

Statistical analysis: An analysis of variance of the data including the rubber yield, vegetative radial growth, latex micro diagnosis, tapping panel dryness was done with SAS statistical software (SAS, 1998) and the StudentNewman-Keuls test, at $\mathrm{P}<0.05$. 
Table 1. Tapping length cut, tapping frequency and hormonal stimulation treatments applied on rubber trees clone

\begin{tabular}{|c|c|c|c|}
\hline $\mathrm{N}^{\circ}$ & Treatment code & Description & $\mathrm{RTI}(\%)$ \\
\hline 1 & $\mathrm{~S} / 2 \mathrm{~d} 26 \mathrm{~d} / 7$ not stimulated (control) & $\begin{array}{l}\text { Half spiral cut tapped downward at alternate daily frequency, six days in tapping followed by one day rest; not } \\
\text { stimulated. }\end{array}$ & 100 \\
\hline 2 & $\mathrm{~S} / 2 \mathrm{~d} 36 \mathrm{~d} / 7$ ET $2.5 \% \mathrm{~Pa} 1(1)$ 4/y(m) & $\begin{array}{l}\text { Half spiral cut tapped downward at third daily frequency, six days in tapping followed by one day rest; stimulated with } \\
\text { Ethephon of } 2.5 \% \text { active ingredient with } 1 \mathrm{~g} \text { of stimulant applied on panel on } 1 \mathrm{~cm} \text { band, } 4 \text { applications per year. }\end{array}$ & 67 \\
\hline 3 & $\mathrm{~S} / 2 \mathrm{~d} 4$ 6d/7 ET 2.5\% Pa 1(1) 4/y(m) & $\begin{array}{l}\text { Half spiral cut tapped downward at fourth daily frequency, six days in tapping followed by one day rest; stimulated with } \\
\text { Ethéphon of } 2.5 \% \text { active ingredient with } 1 \mathrm{~g} \text { of stimulant applied on panel on } 1 \mathrm{~cm} \text { band, } 4 \text { applications per year. }\end{array}$ & 50 \\
\hline 4 & $\mathrm{~S} / 2 \mathrm{~d} 4$ 6d/7 ET 2.5\% Pa 1(1) 8/y(m) & $\begin{array}{l}\text { Half spiral cut tapped downward at fourth daily frequency, six days in tapping followed by one day rest; stimulated with } \\
\text { Ethéphon of } 2.5 \% \text { active ingredient with } 1 \mathrm{~g} \text { of stimulant applied on panel on } 1 \mathrm{~cm} \text { band, } 8 \text { applications per year. }\end{array}$ & 50 \\
\hline 5 & $\mathrm{~S} / 2 \mathrm{~d} 5$ 6d/7 ET 2.5\% Pa 1 (1) 8/y(m) & $\begin{array}{l}\text { Half spiral cut tapped downward at fifth daily frequency, six days in tapping followed by one day rest; stimulated with } \\
\text { Ethéphon of } 2.5 \% \text { active ingredient with } 1 \mathrm{~g} \text { of stimulant applied on panel on } 1 \mathrm{~cm} \text { band, } 8 \text { applications per year. }\end{array}$ & 40 \\
\hline 6 & $\mathrm{~S} / 2 \mathrm{~d} 6$ 6d/7 ET 2.5\% Pa 1(1) 10/y(m) & $\begin{array}{l}\text { Half spiral cut tapped downward at sixth daily frequency, six days in tapping one day rest; stimulated with Ethéphon of } \\
2.5 \% \text { followed by active ingredient with } 1 \mathrm{~g} \text { of stimulant applied on panel on } 1 \mathrm{~cm} \text { band, } 10 \text { applications per year. }\end{array}$ & 33 \\
\hline
\end{tabular}

RTI : Relative tapping intensity (Lukman, 1983; Vijayakumar, 2008; Vijayakumar et al., 2009).

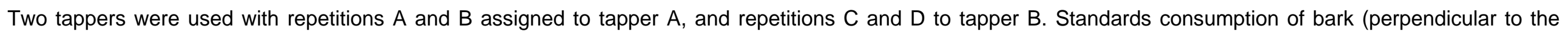
tapping cut) were:

- d2 : 1.0 to $1.3 \mathrm{~mm} /$ tapping, 156 tapping. $\mathrm{y}^{-1}$ (156 to $203 \mathrm{~mm} \mathrm{y}^{-1}$ )

- $\quad$ d3 : 1.3 to $1.5 \mathrm{~mm} /$ tapping, 104 tapping. $y^{-1}\left(135\right.$ to $\left.156 \mathrm{~mm} \mathrm{y}^{-1}\right)$

- $\quad$ d4 : 1.5 to $1.8 \mathrm{~mm} /$ tapping, 78 tapping. $\mathrm{y}^{-1}$ (117 to $\left.140 \mathrm{~mm} \mathrm{y}^{-1}\right)$

- $\quad$ d5 : 1.7 to $2.0 \mathrm{~mm} /$ tapping, 65 tapping. $\mathrm{y}^{-1}$ (110 to $130 \mathrm{~mm} \mathrm{y}^{-1}$ )

- $\quad$ d6 : 1.8 to $2.0 \mathrm{~mm} /$ tapping, 52 tapping. $\mathrm{y}^{-1}$ (93 to $104 \mathrm{~mm} \mathrm{y}^{-1}$ ). 


\section{RESULTS}

Production of rubber: The average production of rubber, grams per tree $\left(\mathrm{g} \cdot \mathrm{t}^{-1}\right)$ on 9 years, varies from $3950 \mathrm{~g}$ (PB 235) to $4940 \mathrm{~g}$ (IRCA 18). This production also had a good level and varied significantly according to the treatment. Indeed, globally the production of control is significantly superior to that of treatments 4 and 5 but comparable to treatments 2 and 3 . The productions $\left(\mathrm{g} \cdot \mathrm{t}^{-1}\right)$ of treatments 2, 3, 4 are statistically comparable (Table 2), except for the clone IRCA 18

TI is tapping intensity : The mean production on 9 years, in kg.ha ${ }^{-1}$ (yield), of treatment 2 is comparable to that of treatments 1 and 3 , but higher than that of treatments 4 and 5 (clone IRCA 18; Table 2). In the case of the clone PB 255, the production of the control is statistically superior to all the other treatments. The values of treatments 2,3 and 4 are close and significantly superior to the average production of the last treatment (5). For the clone PB 235, the first 2 treatments have comparable average productions but superior to that of all the other treatments. However, treatment 2 has an average production comparable to those of treatments 3 and 4 but superior to the production of treatment 5 . This last treatment has a production statistically lower to that of all the other treatments. Concerning the clone IRCA 111, treatments 1, 2, 3 and 4 have comparable productions; the same observation was made for treatments 1, 3, 4 and 5.

Radial bole growth: The tapping bole radial growth, all treatments taken together, reached $2.77 \mathrm{~cm}$ year $^{-1}$ (Table 3). The treatment 1, non-stimulated, gives, with $2.98 \mathrm{~cm}_{\text {.year }}{ }^{-1}$, the highest annual mean increment of girth. The lower increment is that of treatment 3 with $2.66 \mathrm{~cm}$.year ${ }^{-1}$. The annual average increase of treatment 1 (control or non-stimulated) is superior to treatments 2, 3 and 4 (IRCA 18); treatment 4 (PB 255) treatments 3, 4 and 5 (PB 235) treatments 3 and 4 (IRCA 111). All clones considered, the annual average increase of treatment 1 (control) is superior to that of the other treatments. Treatments 2 and 4 have the same increase order. The same is noticed for treatments 3 and 5

\section{Physiological parameters of the latex}

Dry rubber content : The average rate of dry rubber content for all treatments taken together varies from $46 \%$, in the beginning of the experiment, to $54 \%$ at the end. Generally, the dry rubber content rate has an important increase during the experiment. Except for the clone PB 235 where the first 4 presented high values than that of the last treatment (treatment 5), treatment 6 gave higher rate that of all treatments (Table 4).

Sucrose: The latex content in sucrose in the beginning of the trial is $3.9 \mathrm{mM}$ and reaches $6.96 \mathrm{mM}$ at the end, regardless to the clone and the treatment (Table 5). This content in sucrose is characteristic of the active metabolism clones. The latex content in sucrose strongly increases during the experiment as well.

Phosphorus inorganic : The inorganic phosphorus (Pi) average content, all treatments and clones considered varied form $19.1 \mathrm{mM}$ in the beginning of experiment to $21.2 \mathrm{mM}$ at the end. Just a slight increase was seen over the time, which is characteristic of the active metabolism clones. Thus, the inorganic phosphorus (Pi) average content of all treatments was not a limiting factor of the production (Table 6).

Thiols: A decrease was seen for the latex content in thiols which goes from $0.64 \mathrm{mM}$ to reach 0.53 at the end $\mathrm{mM}$, all treatments and clones considered (Table 7). This decrease in thiols content is characteristic of the active metabolism clones; however the latex thiols content of all the treatments is of a good level and significantly lower rate was seen with treatment 1 (control).

Tapping panel dryness: The highest rate of dry trees was found with the control, the non-stimulated treatment while the lowest was observed with treatments 4 and 5 (Figure 1).

Relationship between the production $\left(\mathrm{g} \cdot \mathrm{t}^{-1} \cdot \mathrm{t}^{-1}\right)$ and the intensity of tapping (TI \%)

The production of rubber expressed in $g \cdot \mathrm{t}^{-1} \cdot \mathrm{t}^{-1}$ (average over 9 years) depends on tapping intensity (TI) in a logarithmic relation which general expression is:

$$
\mathbf{P}=\mathbf{a} /\left(\mathbf{1}+\mathrm{TI}^{\mathrm{b}}\right)
$$

This relation becomes (Figure 1; $P<0.001$ ):

$$
\begin{aligned}
& \mathrm{g} \mathrm{t}^{-1} \mathrm{t}^{-1} \text { IRCA 111 }=1469 /\left(1+\mathrm{TI}^{0,81}\right) \\
& \mathrm{g} \mathrm{t}^{-1} \mathrm{t}^{-1} \text { IRCA 18 }=1570 /\left(1+\mathrm{TI}^{0,79}\right) \\
& \mathrm{g} \mathrm{t}^{-1} \mathrm{t}^{-1} \text { PB } 235=1586 /\left(1+\mathrm{TI}^{0,83}\right) \\
& \mathrm{g} \mathrm{t}^{-1} \mathrm{t}^{-1}{ }_{\text {PB } 255}=1598 /\left(1+\mathrm{TI}^{0,81}\right)
\end{aligned}
$$

Relationship between tapping panel dryness (TPD) and intensity of tapping (TI \%)

The rate of tapping panel dryness (TPD) depends on the intensity of tapping ( $\mathrm{TI} \%$ ) in a polynomial relation, quadratic type which general expression is:

TPD $=a T^{2}+b T I+c$ where $a, b$ and $c$ are parameters

This relation becomes (Figure 2; $\mathrm{P}<0.001$ ):

$\checkmark$ TPD IRCA $111(\%)=10^{-3} \mathrm{TI}^{2}-21.10^{-3} \mathrm{TI}+\mathbf{5 . 4 0}$

$\checkmark \quad \operatorname{TPD}_{\operatorname{IRCA}} 18(\%)=3.10^{-3} \mathrm{TI}^{2}-14.10^{-2} \mathrm{TI}+\mathbf{7 . 2 8}$

$\checkmark \operatorname{TPD}_{\mathrm{PB} 235}(\%)=-2.10^{-3} \mathrm{TI}^{2}+28.10^{-2} \mathrm{TI}-1.46$

TPD PB $255(\%)=-3.10^{-3} \mathrm{TI}^{2}+46.10^{-2} \mathrm{TI}-7.47$. 
Agric. Biol. J. N. Am., 2011, 2(8): 1151-1159

Table 2. Annual average production (kg.ha ${ }^{-1}$, g.t $^{-1}$ ) of clones IRCA 111, IRCA 18, PB 235 and PB 255 during 9 years of tapping

\begin{tabular}{|c|c|c|c|c|c|c|c|c|c|}
\hline \multirow[t]{2}{*}{ Tapping systems } & \multirow{2}{*}{$\begin{array}{c}\mathrm{TI} \\
(\%)\end{array}$} & \multicolumn{2}{|c|}{ IRCA 18* } & \multicolumn{2}{|c|}{ PB 255* } & \multicolumn{2}{|c|}{ PB 235* } & \multicolumn{2}{|c|}{ IRCA 111* } \\
\hline & & Kg.ha' & g.t $\mathrm{t}^{-1}$ & $\mathrm{Kg} \mathrm{ha}^{-1}$ & g.t $\mathrm{t}^{-1}$ & $\mathrm{Kg} \mathrm{ha}^{-1}$ & $g \cdot t^{-1}$ & Kg.ha ${ }^{-1}$ & g.t $\mathrm{t}^{-1}$ \\
\hline 1. $\mathrm{d} / 2 \mathrm{o} / \mathrm{y}$ & 100 & $2369 a$ & $5235 a$ & $2127 \mathrm{a}$ & $5050 a$ & $1870 \mathrm{a}$ & $4304 \mathrm{a}$ & $1805 \mathrm{ab}$ & $4910 \mathrm{a}$ \\
\hline 2. $d / 34 / y$ & 67 & $2417 \mathrm{a}$ & $5228 \mathrm{a}$ & $1942 \mathrm{~b}$ & $4663 \mathrm{~b}$ & $1755 a b$ & $4108 \mathrm{ab}$ & $1850 \mathrm{a}$ & $4604 \mathrm{ab}$ \\
\hline 3. $d / 48 / y$ & 50 & $2355 \mathrm{a}$ & $5115 \mathrm{ab}$ & $1879 \mathrm{~b}$ & $4707 \mathrm{~b}$ & $1699 \mathrm{~b}$ & 3979 bc & $1720 \mathrm{ab}$ & $4306 \mathrm{bc}$ \\
\hline 4. $\quad \mathrm{d} / 5 \mathrm{~s} / \mathrm{y}$ & 40 & $2177 \mathrm{~b}$ & $4756 \mathrm{c}$ & $1927 \mathrm{~b}$ & $4325 \mathrm{c}$ & $1675 \mathrm{~b}$ & $3830 \mathrm{c}$ & $1728 \mathrm{ab}$ & $4241 \mathrm{bc}$ \\
\hline $\mathrm{d} / 610 / \mathrm{y}$ & 33 & $1977 \mathrm{C}$ & $4365 d$ & $1633 \mathrm{c}$ & $3816 \mathrm{~d}$ & $1540 \mathrm{c}$ & $3530 \mathrm{~d}$ & $1626 \mathrm{~b}$ & $4055 c$ \\
\hline Ave & age & 2259 & 4940 & 1902 & 4512 & 1708 & 3950 & 1746 & 4423 \\
\hline
\end{tabular}

Table 3. Annual average increments of girth (cm.year ${ }^{-1}$ ) of clones IRCA 111, IRCA 18, PB 255 and PB 235 during 9 years of tapping

\begin{tabular}{|c|c|c|c|c|c|c|}
\hline $\begin{array}{l}\text { Tapping } \\
\text { systems }\end{array}$ & $\mathrm{TI}(\%)$ & IRCA 18* & PB 255* & PB 235* & \multicolumn{2}{|c|}{ IRCA 111 Average } \\
\hline 1. $\mathrm{d} 2 \mathrm{0} / \mathrm{y}$ & 100 & $2.63 a$ & $3.00 \mathrm{a}$ & $3.20 \mathrm{a}$ & $3.1 \mathrm{a}$ & $2.98 \mathrm{a}$ \\
\hline 2. d3 4/y & 67 & $2.42 \mathrm{~b}$ & $2.73 \mathrm{ab}$ & $3.04 \mathrm{ab}$ & $2.8 \mathrm{ab}$ & $2.75 \mathrm{~b}$ \\
\hline 3. $\mathrm{d} 448 / \mathrm{y}$ & 50 & $2.41 \mathrm{~b}$ & $2.73 \mathrm{ab}$ & $2.81 \mathrm{~b}$ & $2.7 \mathrm{~b}$ & $2.66 \mathrm{bc}$ \\
\hline 4. d5 8/y & 40 & $2.85 \mathrm{a}$ & $2.63 \mathrm{~b}$ & $2.78 \mathrm{~b}$ & $2.7 \mathrm{~b}$ & $2.74 \mathrm{~b}$ \\
\hline 5. $\mathrm{d} 6 \mathrm{10} / \mathrm{y}$ & 33 & $2.38 \mathrm{bc}$ & $2.74 \mathrm{ab}$ & $2.81 \mathrm{~b}$ & \multirow{2}{*}{\multicolumn{2}{|c|}{\begin{tabular}{ccc}
\multicolumn{2}{c}{$2.8 \mathrm{ab}$} & $2.68 \mathrm{bc}$ \\
$2.82 \mathrm{ab}$ & 2.77
\end{tabular}}} \\
\hline Average & & $2.54 \mathrm{c}$ & $2.77 \mathrm{abc}$ & $2.93 \mathrm{a}$ & & \\
\hline
\end{tabular}

TI is tapping intensity

Table 4. Evolution of DRC (\%) of clones IRCA 18, PB 255, PB 235 and IRCA 111 during 9 years of tapping

\begin{tabular}{|c|c|c|c|c|c|c|c|c|}
\hline \multirow{2}{*}{$\begin{array}{l}\text { Tapping } \\
\text { systems. }\end{array}$} & \multirow{2}{*}{$\begin{array}{c}\text { TI } \\
(\%)\end{array}$} & \multicolumn{2}{|c|}{ IRCA 18 } & \multicolumn{2}{|c|}{ PB 255 } & \multicolumn{2}{c|}{ PB 235 } & IRCA 111 \\
\cline { 3 - 9 } & & Beginning & End & Beginning & End & Beginning & End & End \\
\hline $\mathrm{d} 20 / \mathrm{y}$ & 100 & $49.2 \mathrm{abc}$ & $51.0 \mathrm{c}$ & $51.9 \mathrm{ab}$ & $50.8 \mathrm{~b}$ & $49.0 \mathrm{a}$ & $55.4 \mathrm{a}$ & 45.2 \\
\hline $\mathrm{d} 34 / \mathrm{y}$ & 67 & $48.1 \mathrm{bc}$ & $55.4 \mathrm{~b}$ & $47.8 \mathrm{~cd}$ & $56.5 \mathrm{a}$ & $37.7 \mathrm{c}$ & $55.1 \mathrm{a}$ & 44.5 \\
\hline $\mathrm{d} 48 / \mathrm{y}$ & 50 & $50.0 \mathrm{ab}$ & $56.9 \mathrm{ab}$ & $45.7 \mathrm{~d}$ & $54.9 \mathrm{a}$ & $50.1 \mathrm{a}$ & $55.2 \mathrm{a}$ & 47.5 \\
\hline $\mathrm{d} 58 / \mathrm{y}$ & 40 & $47.0 \mathrm{c}$ & $56.6 \mathrm{ab}$ & $52.8 \mathrm{a}$ & $58.3 \mathrm{a}$ & $46.8 \mathrm{ab}$ & $54.9 \mathrm{a}$ & 46.7 \\
\hline $\mathrm{d} 610 / \mathrm{y}$ & 33 & $48.9 \mathrm{abc}$ & $57.2 \mathrm{a}$ & $49.8 \mathrm{bc}$ & $57.3 \mathrm{a}$ & $44.9 \mathrm{~b}$ & $41.9 \mathrm{~b}$ & 48.3 \\
\hline Average & $\mathbf{4 8 . 6}$ & $\mathbf{5 . 4}$ & $\mathbf{4 9 . 6}$ & $\mathbf{5 5 . 6}$ & $\mathbf{4 5 . 7}$ & $\mathbf{5 2 . 5}$ & $\mathbf{4 6 . 4}$ \\
\hline
\end{tabular}

$\mathrm{Tl}$ is tapping intensity

Table 5. Evolution of sucrose content (m.mol. I $^{-1}$ ) of clones IRCA 18, PB 255, PB 235 and IRCA 111 during 9 years of tapping

\begin{tabular}{|l|c|c|c|c|c|c|c|c|}
\hline Tapping & \multirow{2}{*}{ systems (\%) } & \multicolumn{2}{|c|}{ IRCA 18 } & \multicolumn{2}{|c|}{ PB 255 } & \multicolumn{2}{c|}{ PB 235 } & IRCA 111 \\
\cline { 3 - 9 } & & Beginning & End & Beginning & End & Beginning & End & End \\
\hline d2 0/y & 100 & 4.0 & $7.5 \mathrm{a}$ & $5.7 \mathrm{a}$ & $9.9 \mathrm{a}$ & 3.8 & $4.7 \mathrm{~b}$ & 6.2 \\
\hline $\mathrm{d} 34 / \mathrm{y}$ & 67 & 3.9 & $7.6 \mathrm{a}$ & $3.6 \mathrm{~cd}$ & $8.3 \mathrm{abc}$ & 3.7 & $6.0 \mathrm{ab}$ & 5.4 \\
\hline $\mathrm{d} 48 / \mathrm{y}$ & 50 & 4.0 & $5.6 \mathrm{bc}$ & $4.4 \mathrm{~b}$ & $6.6 \mathrm{c}$ & 3.2 & $7.2 \mathrm{a}$ & 5.7 \\
\hline $\mathrm{d} 58 / \mathrm{y}$ & 40 & 3.2 & $4.4 \mathrm{c}$ & $4.0 \mathrm{bc}$ & $7.9 \mathrm{abc}$ & 4.0 & $6.6 \mathrm{ab}$ & 7.3 \\
\hline d6 10/y & 33 & 3.7 & $6.0 \mathrm{ab}$ & $3.2 \mathrm{~d}$ & $9.2 \mathrm{ab}$ & 3.8 & $7.2 \mathrm{a}$ & 6.1 \\
\hline Average & & $\mathbf{3 . 8}$ & $\mathbf{6 . 2}$ & $\mathbf{4 . 2}$ & $\mathbf{8 . 4}$ & $\mathbf{3 . 7}$ & $\mathbf{6 . 3}$ & $\mathbf{6 . 1}$ \\
\hline
\end{tabular}

TI is tapping intensity 
Agric. Biol. J. N. Am., 2011, 2(8): 1151-1159

Table 6. Evolution of the Pi content of clones IRCA 18, PB 255, PB 235 and Pi (m.mol. ${ }^{-1}$ ) content at the end of clone IRCA 111 during 9 years of tapping

\begin{tabular}{|c|c|c|c|c|c|c|c|c|}
\hline \multirow{2}{*}{$\begin{array}{l}\text { Tapping } \\
\text { systems }\end{array}$} & \multirow{2}{*}{$\begin{array}{c}\mathrm{TI} \\
(\%)\end{array}$} & \multicolumn{2}{|c|}{ IRCA 18} & \multicolumn{2}{|c|}{ PB 255} & \multicolumn{2}{|c|}{ PB 235} & \multirow{2}{*}{$\frac{\text { IRCA } 111}{\text { End }}$} \\
\hline & & Beginning & End & Beginning & End & Beginning & End & \\
\hline d2 0/y & 100 & $21.2 \mathrm{ab}$ & $26.0 \mathrm{a}$ & $19.4 \mathrm{a}$ & $23.0 \mathrm{a}$ & $21.0 \mathrm{a}$ & $15.8 \mathrm{c}$ & $25.2 \mathrm{bc}$ \\
\hline d3 4/y & 67 & $19.3 \mathrm{~b}$ & $25.4 \mathrm{a}$ & $15.4 \mathrm{c}$ & $25.7 \mathrm{a}$ & $18.5 \mathrm{a}$ & $24.2 \mathrm{a}$ & $28.6 \mathrm{a}$ \\
\hline d4 8/y & 50 & $24.4 \mathrm{a}$ & $17.9 \mathrm{~b}$ & $19.4 \mathrm{a}$ & $19.3 \mathrm{bc}$ & $19.2 \mathrm{a}$ & $18.7 \mathrm{bc}$ & $23.5 \mathrm{c}$ \\
\hline d5 8/y & 40 & $19.6 \mathrm{ab}$ & $16.7 \mathrm{~b}$ & $18.9 \mathrm{a}$ & $18.0 \mathrm{c}$ & $18.1 \mathrm{a}$ & $23.1 \mathrm{ab}$ & $25.6 \mathrm{bc}$ \\
\hline d6 10/y & 33 & $18.8 \mathrm{~b}$ & $24.8 \mathrm{a}$ & $18.5 \mathrm{ab}$ & $22.8 \mathrm{ab}$ & $14.6 \mathrm{~b}$ & $16.9 \mathrm{c}$ & $26.0 \mathrm{~b}$ \\
\hline Average & & 20.7 & 22.2 & 18,3 & 21,8 & 18.3 & 19.7 & 25.8 \\
\hline
\end{tabular}

$\mathrm{TI}$ is tapping intensity

Table 7. Evolution of thiols content of clones IRCA 18, PB 255, PB 235 and thiols (m.mol. $\mathrm{I}^{-1}$ ) content at the end of clone IRCA 111 during 9 years of tapping

\begin{tabular}{|c|c|c|c|c|c|c|c|c|}
\hline Tapping & TI (\%) & \multicolumn{2}{|c|}{ IRCA 18 } & \multicolumn{2}{|c|}{ PB 255 } & \multicolumn{2}{|c|}{ PB 235 } & IRCA 111 \\
\cline { 3 - 9 } systems & & Beginning & End & Beginning & End & Beginning & End & End \\
\hline d2 0/y & 100 & $0.85 \mathrm{a}$ & $0.45 \mathrm{ab}$ & $0.88 \mathrm{~b}$ & $0.66 \mathrm{~b}$ & $0.79 \mathrm{a}$ & $0.33 \mathrm{~d}$ & 0.47 \\
\hline $\mathrm{d} 34 / \mathrm{y}$ & 67 & $0.44 \mathrm{~b}$ & $0.50 \mathrm{a}$ & $1.05 \mathrm{a}$ & $0.74 \mathrm{a}$ & $0.62 \mathrm{~b}$ & $0.57 \mathrm{a}$ & 0.49 \\
\hline $\mathrm{d} 48 / \mathrm{y}$ & 50 & $0.38 \mathrm{bc}$ & $0.44 \mathrm{ab}$ & $0.95 \mathrm{ab}$ & $0.64 \mathrm{~b}$ & $0.43 \mathrm{c}$ & $0.48 \mathrm{abc}$ & 0.36 \\
\hline $\mathrm{d} 58 / \mathrm{y}$ & 40 & $0.38 \mathrm{bc}$ & $0.45 \mathrm{ab}$ & $0.62 \mathrm{c}$ & $0.56 \mathrm{c}$ & $0.41 \mathrm{c}$ & $0.52 \mathrm{ab}$ & 0.42 \\
\hline $\mathrm{d} 610 / \mathrm{y}$ & 33 & $0.39 \mathrm{bc}$ & $0.50 \mathrm{a}$ & $0.93 \mathrm{~b}$ & $0.70 \mathrm{ab}$ & $0.48 \mathrm{c}$ & $0.40 \mathrm{~cd}$ & 0.48 \\
\hline Average & & $\mathbf{0 . 4 9}$ & $\mathbf{0 . 4 7}$ & $\mathbf{0 . 8 9}$ & $\mathbf{0 . 6 6}$ & $\mathbf{0 . 5 5}$ & $\mathbf{0 . 4 6}$ & $\mathbf{0 . 4 4}$ \\
\hline
\end{tabular}

$\mathrm{Tl}$ is tapping intensity

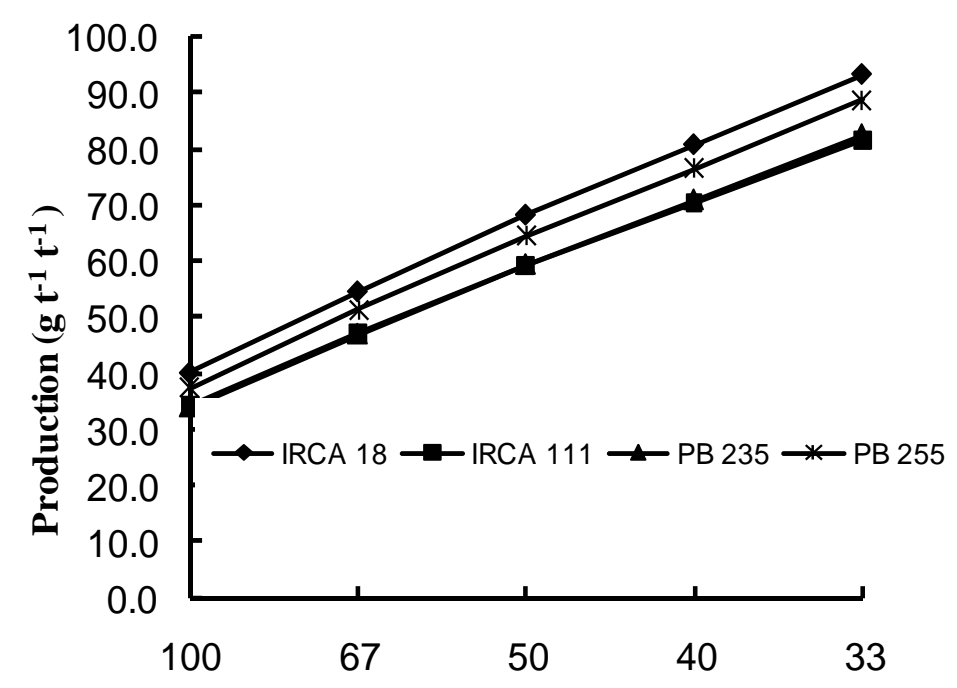

Tapping intensity (TI \%)

Fig 1: Logarithmic relationship between tapping intensity and rubber production $g \cdot \mathrm{t}^{-1} \cdot \mathrm{t}^{-1}$ in Hevea Brasiliensis 
Agric. Biol. J. N. Am., 2011, 2(8): 1151-1159

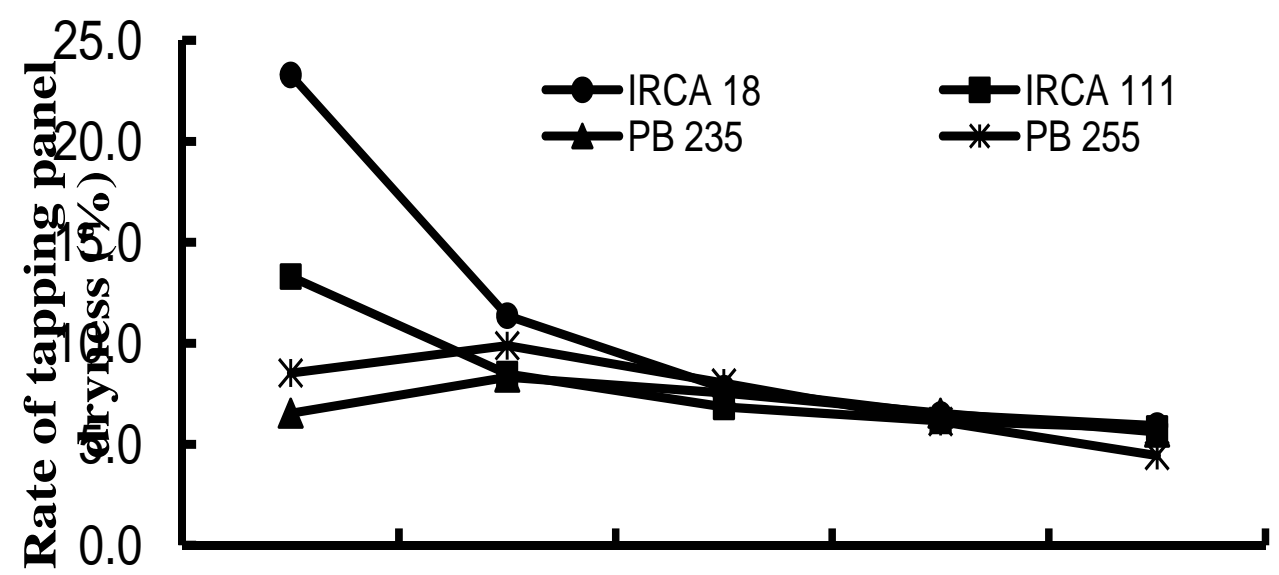

Fig 2: Quadratic relationship between tapping intensity and rate of tapping panel dryness (TPD) of some Hevea brasiliensis clones

\section{DISCUSSION}

The production of rubber per tree and per tapping $\left(g \cdot \mathrm{t}^{-1} \cdot \mathrm{t}^{-1}\right)$, all tapping frequency considered, for the time of downward tapping (first 9 years) is good. Indeed, except the control (S/2 d2 6d/7 without stimulation) which production only represents $73 \%$ of the average in Côte d'Ivoire (46.3 g on 3 years of tapping (Anonymous 1, 1993)) the production of all other treatments is superior to this value of reference. The production g. $\mathrm{t}^{-1} \cdot \mathrm{t}^{-1}$ is inversely proportional to the number of days-off between 2 consecutives tapping. It indicates that the delay between 2 consecutive tapping of the low frequencies of tapping is sufficient to permit a good regeneration of the cellular content exported. However, the frequency of tapping d3 $6 \mathrm{~d} / 7$ appears to be the best to valorize the potentialities of production of the tree and the area tapped of clone IRCA 111. The average production expressed in gram per tree $\left(\mathrm{g} . \mathrm{t}^{-1}\right)$ reaches 4735 , without being raised, is good. This production is positively correlated to the frequency of tapping as well as the yield $\left(\mathrm{kg} \cdot \mathrm{ha}^{-1}\right)$. These relations between the frequency of tapping (notably the intensity of tapping) and the production expressed in $\mathrm{g} \cdot \mathrm{t}^{-1} \cdot \mathrm{t}^{-1}, \mathrm{~g} \cdot \mathrm{t}^{-1}$ and $\mathrm{kg} \cdot \mathrm{ha}^{-1}$ have already been established by Obouayeba and Boa (1993); Obouayeba et al., (1996). The tapping systems applied to the clone IRCA 111, IRCA 18, PB 235 and PB 255 were on the whole a little different from some of the others. Indeed, except weekly tapping stimulated 10 times per year (treatment 5) the rubber productions for other treatments were comparable. Thus treatment 5 appears to be less adapted to the clones which fast metabolic activity requires tapping systems with strong intensity. This is confirmed by the fact that the results on the production, tapping radial bole growth, panel dryness and sensitivity to tapping, reveal that the clones IRCA 111, IRCA 18, PB 235 and PB 255 express their potentialities better with the strong tapping intensity.

The control, 3 weekly tapping without stimulation, cannot be kept among the best tapping systems because of the strong consumption of peel that it generates; 15 to $20 \mathrm{~cm}$.year ${ }^{-1}$ against 9 to $10.5 \mathrm{~cm}$ for the treatment $d 66 \mathrm{~d} / 7$. It didn't permit to follow the active tapping panel conduct diagram, from the $7^{\text {th }}$ year of tapping. In the same way, this treatment presents a strong sensitivity to tapping panel dryness, which constitutes a heavy handicap for its promotion. The productions of rubber by tree $\left(\mathrm{g} \cdot \mathrm{t}^{-1}\right)$ and by area $\left(\mathrm{kg} \mathrm{ha}^{-1}\right)$ indicate that the strong frequencies of tapping have proved to be more efficient on the clones used in this study than those of low tapping frequencies. To appreciate the capacity in the plantation of IRCA 111, IRCA 18, PB 235 and PB 255, the number of tapping per year appears to be more suitable than the delay separating two consecutive tapping, which is in agreement with Obouayeba and Boa (1993) while studying the clone PB 235. In contrast, in the case of the work productivity (the one of tapper) and of the one of the tree, it is rather the number of days between two 
consecutive tapping that is the essential parameter. Thus the results could be used in two ways:

- for an optimal exploitation of the potentialities of the clones IRCA 111, IRCA 18, PB 235 and PB 255 the tapping system 2 , two weekly tapping with 4 yearly stimulations, is the best of the treatments used.

- to face a shortage and/or dearness of tappers, the last treatment (tapping system 5) weekly tapping stimulated 10 times per year, is the most suitable tapping system.

Otherwise we put in evidence two types of relation from the intensity of tapping (IT). The production by tree and by tapping $\left(\mathrm{g} \cdot \mathrm{t}^{-1} \cdot \mathrm{t}^{-1}\right)$ is, indeed, in logarithmic relation with the intensity of tapping, the $g \cdot \mathrm{t}^{-1} \cdot \mathrm{t}^{-1}$ is especially weak than the intensity of tapping is strong and vice-versa. It is important and corroborates the results of previous studies (Jacob et al., 1988a, b; Obouayeba and Boa, 1993; Obouayeba et al., 1996) that indicate the importance of the regeneration time between two consecutive tapping. The active clones express their potentiality of production better according to tapping intensity but the very strong intensities (d2) are a handicap to the expression of their value. Since the period of 2 days that separates two consecutive tapping is obviously long and doesn't allow the laticiferous to insure a sufficient synthesis of the isoprenic. When the time of regeneration is long the laticiferous achieve a good isoprenic biosynthesis (rubber) and this production can last for a long time since the laticiferous is in good conditions for its development. On the other hand, when this time of regeneration is too short the isoprenic biosynthesis is bad, leading to a poor rubber production. Moreover, in the latter case, the lack of an appropriate physiological break could sometimes result in the tapping panel dryness. Thus, our results show that the tapping panel dryness (TPD \%) rate is linked to the tapping intensity by quadratic relation (Obouayeba et al., 2009). This relation is an indication which shows that among the clones of active metabolism the sensitivity to tapping panel dryness depends on the intensity of tapping applied to the rubber trees regardless to the clone. These results confirm the idea that the tapping panel dryness induction might have at least two origins. One that depends on the tapping systems applied to the trees; in this case the tapping panel dryness is often reversible while reducing the intensity of exploitation. Another one which roots are physiological, however little is known so far on the mechanism governing its apparition. What is more reported, is the tie of tapping panel dryness with all phenomenon of stress regardless the nature and the origin of the later. Our results show that the treatment 2, tapping 2 times per week and stimulated 4 times per year is the best of the 5 tapping systems applied to the 4 clones of rubber tree (Hevea brasiliensis).

\section{CONCLUSION}

This survey has shown that the clones IRCA 18, IRCA 111, censuses made in Côte d'Ivoire, belong to the class of active clones having fast metabolic activity, like the clones PB 235 and PB 255. These clones also confirmed their adherence to the group of high rubber producer clones. This survey also showed that the production of a tree for the tapping strongly depends on the intensity of tapping. It has been indicated that the intensity of tapping governed the tapping panel dryness rate among the clones having active metabolism, notably IRCA 18, IRCA 111, PB 235 and PB 255. The tapping system S/2 d3 $6 \mathrm{~d} / 74 / \mathrm{y}$, that is two weekly tapping in half spiral descendant, stimulated 4 times per year, is the best of the 5 tapping systems studied.

\section{ACKNOWLEDGEMENTS}

This study was supported by the Hevego S.A., Société Hévéicole du GO, San Pedro Côte d'Ivoire and the CNRA, Research Station of Bimbresso. Thanks are due to directors, Mr K. Konaté and $\mathrm{Dr}$ YO Tiémoko, specialists and assistants such as Coulibaly Fanlégué, Gabla Oulay, Doumbia Amadou for their technical helping.

\section{REFERENCES}

Abraham, P.D., P'NG, T.C., Lee, C.K., Sivakumaran, S., Manikam, B and Yeoh, C.P (1975). Ethrel stimulation of Hevea. Proceedings of Institut of Rubber Conference. RRIM-Kuala Lumpur 1975, 2, 347.

Anonyme 1, (1993). Fiches de clones 4, 11 et 12 : GT 1, PB 217 et PB 235. In: Recueil de Fiches de clones (document interne) $5 \mathrm{p}$.

Bealing, F.J and CHUA, J.E (1972). Output, composition and metabolic activity of Hevea latex in relation to tapping intensity and the Onset of Brown Bast J. Rubb. Res. Inst. Malaya, 23(3), 204 -231.

Chew, J.S., Gan, L.T., Ho, C.Y., Tiong, M.D., Sivakurmaran, S., Chong, $\mathrm{K}$ and Shmad, Z.M.T (1995). Periodic tapping system : sime darby's Experience.Proceeding Rubber Growers' conference 1995.

Chong, K and Sivakumaran, S (1995). Performance of low frequency tapping systems. In: Proceedings of workshop on exploitation technologies to address 
current labour problems in the rubber industry. Kuala Lumpur 1994, pp 47-69.

Gener, P and Du Plessix, J.C (1975). Effective Use of tapping systems and stimulation methods towards rational Exploitation of Hevea. In: Proceedings of the International Rubber conference 1975, Kuala Lumpur 384-395.

Jacob, J and Krishnakumar, R (2005). Tapping Panel Dryness syndrome: what we know and whatwe do not know. In: Tapping Panel Dryness of Rubber Trees. Eds James Jacob,Krishnakumar R. and Mathew, N.M. 2006, Rubber Research Institute of India, Kottayam, pp 1-27.

Jacob, J.L., Prevôt, J.C and Lacrotte, R (1994). L'encoche sèche chez Hevea brasiliensis. Plantations, recherche, développement, 1 (3) 15-24.

Jacob, J.L., Serres, E., Prévôt, J.C., Lacrotte, R., Vidal, A Eschbach, J.M and d'Auzac, J (1988). Mise au point d diagnostic latex. Agritrop, 12, 97-118.

Lee, C.K and Hashim, J (1989). Effects of exploitation systems on panel dryness. Proc. RRIM Rubb.Grower's Conf., 1989, Malacca, Malaysia, pp. 334-347.

Li, Z.Y (1982). The relationship of brown bast of rubber trees and over exploitation. Chin. J. Trop.Crop Sci. Technol., 5: 12-16.

Lukman, (1983). Special Communication. Revised International Notation for exploitation systems. J. Rubb. Res. Inst. Malaysia, 31 (2) 130-140.

Nair, N.U (2004). Tapping panel dryness survey in smallholdings. IRRDB Conf., NR Industry: Responding to Globalization, 2004, Kunming, China, pp. 1-7.

Obouayeba, S., Soumahin, E.F., Dobo, M., Lacote, R., Gabla, $O$ and Doumbia, A (2009). Agronomic performance of clone IRCA 111 of Hevea brasiliensis under different frequencies of tapping and stimulation in South-West Côte d'Ivoire. Journal of Rubber Research. 12(2), 93-102.

Obouayeba, S and Boa, D (1993). Fréquence et repos annuel de saignée d'Hevea brasiliensis, clone PB 235, dans le sud-est de la Côte d'Ivoire. Cahiers Agricultures (2) 387-393.

Paardekooper, E.C (1989). Exploitation of the rubber tree. In Rubber eds. CC Wesbster et W. J. Baulkwill, pp 349414. London : Longmans.

Premakumari, D., Panikkar, A.O.N., Sethuraj, M.R and Marattukalam, J.G (1997). Association of structural traits: Yield, Growth and occurrence of tapping panel dryness in Hevea brasiliensis. Ind. J. Nat.Rubb. Res., 10(1\&2):27-33.

Premakumari, D., Panikkar, A.O.N., Sethuraj, M.R and Marattukalam, J.G (1997). Growth, Yield and flow characters and their correlations with brown bast incidence in ten Hevea clones. Ind. J. Nat. Rubb.Res., 4(2): 107-113.

'SAS (1998) SAS/STAT User' Guide, Version 6.03, SAS Institute, Cary, NC.

Sethuraj MR (1988) A conceptual analysis of brown bast syndrome. Compte-rendu Colloque Exploitation Physiologie et amélioration de l'Hevea, Paris, France. pp. 247-351.

Vijayakumar, K.R (2008) Revised international notation for latex production technology. IRRDB Workshop of Latex Harvesting Technologies, Sungai Buloh, Selangor, 5-8 May 2008. 20 p.

Vijayakumar, K.R, Thomas, K.U, Rajagopal, R and Karunaichamy, K (2006). Management of fields affected by severe incidence of Tapping Panel Dryness. In: Tapping panel dryness of rubber trees (Eds. James Jacob, R. Krishnakumar and N.M. Mathew). Rubber Research Institute of India. Kottayam. pp. 207-215. 